\title{
Morphophysiological characterization of Ceratocystis fimbriata isolates from yerba mate
}

\author{
Nícolas Manarim de Brito ${ }^{1}$ Henrique da Silva Silveira Duarte ${ }^{1}$ Caroline de Bastos Bühner $^{2}$ (D) \\ Celso Garcia $\mathrm{Auer}^{2}$ (D) Álvaro Figueredo dos Santos ${ }^{2 *}$ (D)
}

${ }^{1}$ Departamento de Fitotecnia e Fitossanidade, Universidade Federal do Paraná (UFPR), Curitiba, PR, Brasil.

${ }^{2}$ Empresa Brasileira de Pesquisa Agropecuária, Embrapa Florestas, 83411-000, Colombo, PR, Brasil. E-mail: alvarofigueredo@gmail.com. ${ }^{*}$ Corresponding author.

\begin{abstract}
This study aimed to morphologically characterize the isolates of Ceratocystis fimbriata from yerba mate and to evaluate the effect of culture medium and temperature on mycelial growth and sporulation of C. fimbriata. For the morphological characterization of the 11 monosporic isolates of the fungus, slides were prepared to determine the dimensions of the sexual and asexual structures of the fungus. Four experiments were conducted to evaluate the mycelial growth and to evaluate the sporulation of C. fimbriata in different culture mediums and temperatures. The isolates of C. fimbriata from yerba mate showed perithecia with brown to black necks, divergent ostiolar hyphae, hatshaped hyaline ascospores, single-celled, cylindrical endoconidia, and globular to ovoid aleurioconidia. PDA and V8-agar media showed the highest mycelial growth. The average optimum temperature for mycelial growth and sporulation of isolates of C. fimbriata of yerba mate were 22.5 and $22.4{ }^{\circ} \mathrm{C}$, respectively.

Key words: Ilex paraguariensis, fungus, Vascular wilt.
\end{abstract}

Caracterização morfofisiológica de isolados de Ceratocystis fimbriata de erva-mate

RESUMO: Este estudo teve como objetivo caracterizar morfologicamente os isolados de Ceratocystis fimbriata e avaliar o efeito do meio de cultura e da temperatura no crescimento micelial e na esporulação de C. fimbriata. Para a caracterização morfológica dos 11 isolados monospóricos do fungo foram preparadas lâminas para determinar as dimensões das estruturas sexuadas e assexuadas do fungo. Quatro experimentos foram conduzidos para avaliar o crescimento micelial e esporulação of C. fimbriata em diferentes meios de culturae temperaturas. Os isolados de C. fimbriata de erva-mate apresentaram peritécios com pescoço de marrom a preto, hifa ostiolar divergente, ascósporos hialinos em formato de chapéu, endoconídios unicelulares, cilíndricos, e aleuroconídios com formato globoso a ovoide. Os meios de cultura PDA e V8-ágar apresentaram os maiores crescimentos miceliais. A temperatura ótima média para crescimento micelial e esporulação dos isolados de C. fimbriata de erva-mate foram de 22,5 e $22,4{ }^{\circ} \mathrm{C}$, respectivamente.

Palavras-chave: Ilexparaguariensis, fungo, Murcha vascular.

In 2018, in some commercial plantations of yerba mate (Ilex paraguariensisA. St. -Hil.) located in São Mateus do Sul, PR and Arvorezinha, RS, mortality of up to $5 \%$ of the plants was reported due to the wilting of yerba mate caused by Ceratocystis fimbriata Ellis \& Halsted (SANTOS et al. 2018). This disease can become limiting for the cultivation of yerba mate. Therefore, it is important to obtain information about this pathosystem to develop strategies to control the disease.

In Brazil, only three species of Ceratocystis are found: $C$. paradoxa, which infects mainly monocots (SANTOS et al. 2017); C. cacaofunesta, which causes losses in cacao plantations (SILVA et al. 2007); and C. fimbriata, which attacks many woody plants (FERREIRA et al. 2013). Therefore, more indepth morphological studies, including macroscopic and microscopic characteristics, are essential tools in the taxonomic studies of Ceratocystis in yerba mate. In phytopathological studies, it is important to know about the conditions that favor fungal mycelial growth and sporulation. The artificial culture media should simulate the natural environmental conditions, containing nutrients in adequate proportions for the maintenance and multiplication of microorganisms. Temperature is another important factor for the mycelial growth of $C$. fimbriata and sporulation can vary within the species and between isolates of the same species, allowing fungi to express their maximum metabolic potential. In this 
work, the objective was to characterize the isolates of $C$. fimbriata morphologically and to evaluate the effect of culture medium and temperature on mycelial growth and sporulation of C. fimbriata.

The experiments were carried out at the Forest Pathology Laboratory of Embrapa Florestas, Colombo, PR. Eleven monosporic isolates of $C$. fimbriata belonging to the collection of Forest Fungi and Oomycetes of Embrapa Florestas were used. The isolates came from symptomatic samples of yerba mate plants collected in 2016 from two regions: isolates C-1, C-2, C-3 and C-4 are from São Mateus do Sul, PR and isolates C-5, C-6, C-7, C-8, C-9, C-10 and $\mathrm{C}-11$ are from Arvorezinha, RS. The isolates were stored in the Castellani method with sodium chloride solution $0.85 \%$ to ensure the viability of the isolates. The 11 isolates were identified morphologically following characteristics of the species C. fimbriata (SANTOS \& FERREIRA, 2003). To obtain greater reliability of morphological identification, isolates C-1, C-4 and C-8 were identified molecularly following the methodology described by SANTOS et al. (2018) as C. fimbriata.

To morphological characterization of Ceratocystis fimbriata, 11 isolates of $C$. fimbriata were grown for 15 days in PDA medium in a BOD growth chamber at $24{ }^{\circ} \mathrm{C}$, in a $12 \mathrm{~h}$ light/ $12 \mathrm{~h}$ dark photoperiod. After, the portions of the fungus were collected with a loop and deposited on a microscope slide with a drop of methylene blue dye and examined under Microscope Zeiss Axio Lab.A1 with Zen 2.3 lite software. In a 100x magnification, were determined: the width and length measurements of the ascomatal base; the length of the perithecia neck; the width of the base and the apex of the neck. At 400x magnification, were determined: the length of the ostiolar hyphae; the length and width of the ascospore; the length of the endoconidiophore and the width of the base and the widest point; the length and width of the conidia and the length and width of the chlamydospore. For each fungal structure, 100 repetitions were performed. Data of the morphological characterization of the 11 isolates were compared with the results of the morphological characterization of isolates of $C$. fimbriata from rubber tree (VALDETARO, 2012), eucalyptus (FERREIRA et al. 2013) and kiwi (PIVETA, 2013).

To evaluate the mycelial growth and sporulation of $C$. fimbriata in different culture media, two experiments were conducted following a completely randomized design with 3 treatments (culture media) and 3 replicates. Each replicate consisted of a Petri dish (90 $\mathrm{mm}$ diameter). The three culture media used were: a) potato-dextroseagar (PDA-Kasvi ${ }^{\circledR}$ ) (42 $\mathrm{g}$ of powdered PDA, $1 \mathrm{~L}$ of ultrapure water); b) V8-agar (200 $\mathrm{mL}$ of V8-agar juice, $3 \mathrm{~g}$ of $\mathrm{CaCO}_{3}, 20 \mathrm{~g}$ of agar and $800 \mathrm{~mL}$ of distilled water); c) carrot-agar (CA) (200 g of carrot scraped and cut into slices, $500 \mathrm{~mL}$ of distilled water). All media were autoclaved at $121^{\circ} \mathrm{C}$ for $15 \mathrm{~min}$ and poured into Petri dishes. Disks of $5 \mathrm{~mm}$ in diameter of the isolate C-6 of C. fimbriata were transferred to the center of each Petri dish. These Petri dishes were maintained in a BOD growth chamber at $24{ }^{\circ} \mathrm{C}$ under $12 \mathrm{~h}$ light and $12 \mathrm{~h}$ dark photoperiod. Evaluation of mycelial growth consisted in the measurement of two diametrically opposed measures with the aid of a digital caliper 15 days after the experiment installation. After measuring mycelial growth, sporulation was evaluated obtaining concentration of spores (ascospores, endoconidia and aleurioconidia) determined with a hemacytometer. After obtaining the data, a descriptive statistic of the results was performed using R software (R Core Team 2020).

To evaluate mycelial growth and sporulation of $C$. fimbriata at different temperature ranges, two experiments was conducted by a completely randomized design using 8 treatments and 3 replicates, each replicate being composed of one Petri dish (90 $\mathrm{mm}$ diameter) per isolate for each temperature. The temperatures evaluated were: $8,12,16,20,24,28,32$ and $36^{\circ} \mathrm{C}$. PDA disks of $5 \mathrm{~mm}$ in diameter were placed at the center of Petri dishes containing PDA media and the evaluation of the mycelial growth and sporulation was performed in the same way as the experiment that evaluated the different culture media. The results obtained were subjected to a quadratic regression analysis to obtain the optimal growth temperature and sporulation for each of the 11 isolates. The statistical analyses were performed using R software (R Core Team 2020).

The morphological data of the sexual and asexual structures obtained from the 11 isolates of $C$. fimbriata obtained from yerba mate and from the hosts rubber tree, eucalyptus and kiwi are shown in Table 1. The isolates presented superficial or submerged in the substrate perithecia, with color ranging from brown to black at the base, with 94.6 $353.8 \mu \mathrm{m}$ in length and $79.0-330.8 \mu \mathrm{m}$ in width. The neck of the perithecia showed the same coloration as the base and its length varied from 254.7 - 1354.4 $\mu \mathrm{m}$, the diameter of the base of the neck measured $21.7-52.0 \mu \mathrm{m}$ and $14.1-26.8 \mu \mathrm{m}$ at the distal end (Table 1, Figure 1B). Ostiolar hyphae are divergent, light brown to hyaline, not septate, measuring $23.5-72.6 \mu \mathrm{m}$ in length (Table 1, Figure 1A). The 
Table 1 - Comparison of the morphological structures of isolates of Ceratocystis fimbriata from yerba mate with isolates from rubber tree, eucalyptus, and kiwi.

\begin{tabular}{|c|c|c|c|c|}
\hline \multirow[t]{2}{*}{ Structures } & \multicolumn{4}{|c|}{ 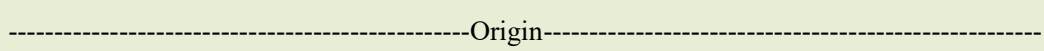 } \\
\hline & $\begin{array}{l}\text { Yerba mate } \\
\text { (This study) }\end{array}$ & $\begin{array}{c}\text { Rubber } \\
\text { (VALDETARO, 2012) }\end{array}$ & $\begin{array}{c}\text { Eucalyptus } \\
\text { (FERREIRA et al.,2013) }\end{array}$ & $\begin{array}{c}\text { Kiwi } \\
\text { (PIVETA, 2013) }\end{array}$ \\
\hline Number of isolates & 11 & 4 & - & 4 \\
\hline \multicolumn{5}{|l|}{ Ascomatal base } \\
\hline Length $(\mu \mathrm{m})$ & $94.6-353.8^{*}$ & $120.0-252.0$ & $120.0-250.0$ & $70.0-234.0$ \\
\hline Width $(\mu \mathrm{m})$ & $79.0-330.8$ & $115.0-241.0$ & $110.0-250.0$ & $86.0-250.0$ \\
\hline \multicolumn{5}{|l|}{ Ascomatal neck } \\
\hline Length $(\mu \mathrm{m})$ & $254.7-1354.4$ & $172.0-668.0$ & $440.0-770.0$ & $143.0-721.0$ \\
\hline Width (base) $(\mu \mathrm{m})$ & $21.7-52.0$ & $23.0-59.0$ & $28.0-40.0$ & $22.0-48.0$ \\
\hline Width (apex) $(\mu \mathrm{m})$ & $14.1-26.8$ & $14.0-24.0$ & $16.0-24.0$ & $10.0-34.0$ \\
\hline \multicolumn{5}{|l|}{ Ostiolar hyphae } \\
\hline Length $(\mu \mathrm{m})$ & $23.5-72.6$ & $53.0-98.0$ & $20.0-120.0$ & $29.0-98.0$ \\
\hline \multicolumn{5}{|l|}{ Ascospore } \\
\hline Length $(\mu \mathrm{m})$ & $3.6-5.9$ & $5.0-7.0$ & $4.5-8.0$ & $4.0-6.0$ \\
\hline Width $(\mu \mathrm{m})$ & $1.8-3.4$ & $3.0-4.0$ & $2.5-5.5$ & - \\
\hline \multicolumn{5}{|l|}{ Endoconidiophore } \\
\hline Length $(\mu \mathrm{m})$ & $15.9-53.1$ & $51.0-240.0$ & $55.0-120.0$ & $29.0-88.0$ \\
\hline Width (base) $(\mu \mathrm{m})$ & $3.1-6.4$ & $2.0-5.0$ & $3.0-8.0$ & $2.0-7.0$ \\
\hline \multicolumn{5}{|l|}{ Endoconidia } \\
\hline Length $(\mu \mathrm{m})$ & $8.5-27.6$ & $10.0-22.0$ & $9.0-33.0$ & $9.0-21.0$ \\
\hline Width $(\mu \mathrm{m})$ & $3.2-6.6$ & $3.0-5.0$ & $3.0-5.0$ & $3.0-5.0$ \\
\hline \multicolumn{5}{|l|}{ Aleurioconidia } \\
\hline Length $(\mu \mathrm{m})$ & $9.7-15.3$ & $13.0-18.0$ & $11.0-16.0$ & $9.0-14.0$ \\
\hline Width $(\mu \mathrm{m})$ & $7.1-12.2$ & $8.0-14.0$ & $6.5-12.0$ & $6.0-11.0$ \\
\hline
\end{tabular}

*Minimum and maximum value found for each fungus structure, (-) data not found.

ascospores are hyaline, small, hat-shaped and are 3.6 - $5.9 \mu \mathrm{m}$ long and $1.8-3.4 \mu \mathrm{m}$ wide, accumulated in a cream-colored matrix at the end of the perithecium (Table 1, Figure 1C). Endoconidiophores originate laterally from vegetative hyphae with dimensions of $15.9-53.1 \mu \mathrm{m}$ in length and $3.1-6.4 \mu \mathrm{m}$ in width at the base (Table 1, Figure 1E). The endoconidia are unicellular, hyaline to light brown, cylindrical with dimensions 8.5 - $27.6 \mu \mathrm{m}$ in length and $3.2-6.6 \mu \mathrm{m}$ in width. The aleurioconidia are $9.7-15.3 \mu \mathrm{m}$ long and $7.1-12.2 \mu \mathrm{m}$ wide (Table 1, Figure 1D).

The three tested culture media provided mycelial growth and sporulation of $C$. fimbriata. PDA and V8-agar media showed the highest mycelial growth. There was no difference in sporulation when PDA, CA and V8-agar culture media were used.

The average optimum temperature for the maximum mycelial growth of the 11 isolates of $C$. fimbriata was $22.5^{\circ} \mathrm{C}$, in a temperature range that varied from 22.2 to $23.1{ }^{\circ} \mathrm{C}$. The average optimal temperature for the maximum sporulation of the 11 isolates of C. fimbriata was $22.4^{\circ} \mathrm{C}$, in a temperature range that varied from 21.7 to $23.5^{\circ} \mathrm{C}$. There was no mycelial growth below $8{ }^{\circ} \mathrm{C}$ and above $36^{\circ} \mathrm{C}$. The isolates of $C$. fimbriata from yerba mate showed superficial or submerged in the substrate perithecia, with color ranging from brown to black both at the base and neck of the perithecium, similar to the results in rubbertree (VALDETARO, 2012), in eucalyptus (FERREIRA et al. 2013) and kiwi (PIVETA, 2013). However, there were greater dimensions for length and width of the ascomatal base and neck of the perithecium; results that approach the values found in eucalyptus (FIRMINO, 2011). For the data on the width of the base and the apex of the neck, the values found are close to the values presented by Ferreira et al (2013) and Valdetaro (2012). The ostiolar hyphae is divergent, light brown to hyaline, not septate. The minimum values obtained for ostiolar hyphae are slightly below the values found by Valdetaro 


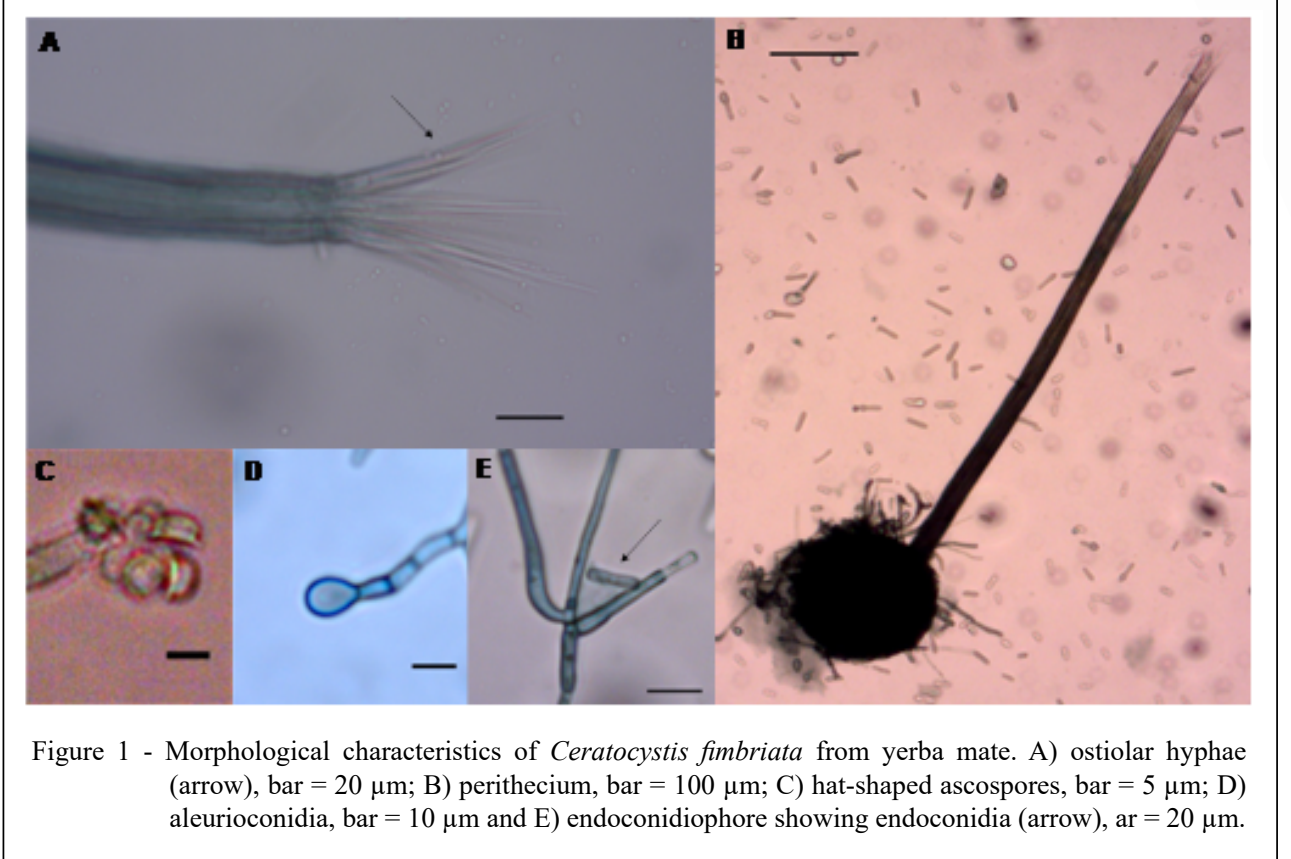

(2012) and Piveta (2013), but they are distributed within the minimum $(20 \mu \mathrm{m})$ and maximum $(120$ $\mu \mathrm{m})$ measurement ranges found by Valdetaro (2012), Ferreira et al (2013) and Piveta (2013).

The ascospores of yerba mate isolates are hyaline, small, hat-shaped and are accumulated in a cream-colored matrix at the end of the perithecium, with lengths (3.6 - 5.9) similar to the values found by Ferreira et al. (2013) $(4.5-8.0 \mu \mathrm{m})$ and Valdetaro (2012) $(5.0-7.0 \mu \mathrm{m})$, in eucalyptus and rubber tree, respectively. However, the values for width were slightly lower, $1.8-3.4 \mu \mathrm{m}$ for the isolates of this work, and $3.0-4.0 \mu \mathrm{m}$ for the isolates of Valdetaro (2012), in rubber. The endoconidiophores originate laterally from the vegetative hyphae, having the length and width values following the ones obtained by Valdetaro (2012), Ferreira et al. (2013) and Piveta (2013), with a caveat in the minimum values found for the isolates obtained from yerba mate where the smallest length measurement was $82 \%$ less than the values obtained by Piveta (2013).

The isolates of $C$. fimbriata showed the highest values for mycelial growth in the PDA and V8-agar media, while Souza (2015) found that the greatest mycelial growth of the anamorph stage of Ceratocystis sp. was in the PDA medium. In the present study, there were no differences between the three culture media tested for the sporulation of C. fimbriata, however in a study also performed by Souza (2015) with an anamorph of $C$. fimbriata, the largest sporulation obtained was in PDA medium.

The isolates of $C$. fimbriata showed a small difference in optimum temperatures for both mycelial growth and sporulation. The average optimum temperature for mycelial growth and sporulation of isolates of C. fimbriata from yerba mate were 22.5 and $22.4^{\circ} \mathrm{C}$, respectively. These values approximate those found for C. fimbriata kiwi isolates from Farroupilha, RS, which were between 20 and $25{ }^{\circ} \mathrm{C}$ (PIVETA, 2013).

The C. fimbriata isolates were stored in the Castellani method for two years before the experiments were carried out. This preservation method was used because it is most appropriate, therefore beyond being efficient in the viability maintenance, sporulation and pathogenicity, reduce a probability of mutations and contamination mites (APARECIDO \& FINATTI, 2012).

The information obtained in this work will serve as a basis for future research such as epidemiological studies, identification of adequate control measures and other tests in which the determination of the morphophysiological characteristics of the pathogen of the disease are necessary. 


\section{ACKNOWLEDGEMENTS}

This study was financed in part by the 'Coordenação de Aperfeiçoamento de Pessoal de Nível Superior - Brasil' (CAPES) - Finance Code 001. The HSSD, CGA and AFS authors thanks the 'Conselho Nacional de Desenvolvimento Científico e Tecnológico’ (CNPq)/Brazil for its research fellowship.

\section{DECLARATION OF CONFLICTS OF INTERESTS}

We have no conflict of interest to declare.

\section{AUTHORS' CONTRIBUTIONS}

All authors contributed equally to the design and writing of the manuscript. All authors critically reviewed the manuscript and approved the final version.

\section{REFERENCES}

APARECIDO, C. C., FINATTI, D. Preservação em laboratório de fungos filamentosos por longos períodosde tempo. Biológico, v.74, n.1, p.9-16, 2012. Available from: <http://www.biologico sp.gov.br/uploads/docs/bio/v74_1/pires.pdf $>$. Accessed: Aug. 12, 2020 .

FERREIRA, M. A. et al. Ceratocystisfimbriata em espécies florestais e agronômicas no Brasil. In:__. Núcleo de Estudos em Fitopatologia. (Org.). Patologia florestal: desafios e perspectivas. 1ed. São Carlos: Suprema Gráfica e Editora, 2013, p. $75-101$.

FIRMINO, A. C. Caracterização de isolados de Ceratocystis sp., avaliação de resistência clonal de eucalipto $e$ sensibilidade deste fungo a diferentes fungicidas. 2011. 59f. Tese (Doutorado em Agronomia - Proteção de Plantas) - Curso de Pós-graduação em Agronomia, Faculdade de Ciências Agronômicas, Universidade Estadual Paulista.
PIVETA, G. Morfologia, caracterização molecular e patogenicidade de Ceratocystis fimbriata no Rio Grande do Sul. 2013. 66 f. Tese (Doutorado em Engenharia Florestal) - Curso de Pós-graduação em Engenharia Florestal, Universidade Federal de Santa Maria.

R Core Team. The R Project for statistical computing, 2020 Avaible from: <https://www.rproject.org/>. Accessed: Mar. 30, 2020.

SANTOS, A. F. dos et al. First report of Yerba Mate wilt caused by Ceratocystis fimbriata in Brazil. Plant Disease, v.102, n.11, p.2381, 2018. Available from: <https://doi.org/10.1094/PDIS-0218-0228-PDN>. Accessed: May, 12, 2020.

SANTOS, A. F. dos, FERRERA, F. A. Ceratocystis wilt of black wattle in Brazil. Fitopatologia Brasileira, v.28, n.3, p.325, 2003. Available from: <http://dx.doi.org/10.1590/S010041582003000300020>. Accessed: May, 12, 2020.

SANTOS, P. H. D. et al. Diagrammatic scale of severity for postharvest black rot (Ceratocystisparadoxa) in coconut palm fruits. Summa Phytopathologica, v.43, n.4, p.269-275. 2017. Available from: <https://doi.org/10.1590/0100-5405/170792>. Accessed: May, 12, 2020.

SILVA, S. D. V. M. et al. Reação de genótipos de cacaueiros a isolados de Ceratocystiscacaofunesta. Fitopatologia Brasileira, v.32, n.6, p.504-506. 2007. Available from: <http://dx.doi. org/10.1590/S0100-41582007000600009>. Accessed: May, 12, 2020

SOUZA, W. C. O. et al. Comportamento in vitro de Chalaraparadoxa, agente causal da podridão-negra do abacaxizeiro, em diferentes condições de cultivo. Revista Brasileira de Fruticultura Jaboticabal, v.37, n.4, p.845-851, 2015. Available from: <http:// dx.doi.org/10.1590/0100-2945-192/14>. Accessed: May, 12, 2020.

VALDETARO, D.C.O.F. Morfologia, Variabilidade Genética e Patogenicidade de Ceratocystis fimbriata em Hevea brasiliensis. 2012. 28f. Dissertação (Mestrado em Fitopatologia) - Curso de Pós-graduação em Fitopatologia, Universidade Federal de Viçosa. 